\title{
Child Labour: A Rational Response to Economic Incentives
}

\author{
Asima Shirazi and Dr. Amanat Ali Jalbani \\ SZABIST \\ Karachi, Pakistan
}

\begin{abstract}
:
This paper is a situational analysis of child labour in Pakistan. Child labour is a pervasive phenomenon in many developing countries. It is the symptom of several ailments the economy is suffering from and cannot be eliminated simply by passing legislation. Legislation to ban child labour has to be accompanied with other policies that alleviate poverty and ensure a well functioning safety net.
\end{abstract}

\section{Introduction}

Officially there are 3.3 million children between the ages of 5 and 15 already in the workforce in Pakistan. The unofficial estimates for child labour are around 8 million. Why are children sent to work? Is it the selfishness of parents or is it an economic necessity? These are some of the issues addressed in this paper. The presence of child labour is an example of market failure and needs government intervention. An economic framework is used to analyse the sources of market failure and some policy prescriptions are made.

\section{Child Labour in General}

Child Labour has attracted considerable media, academic and government attention recently. There is an expression of commitment from NGOs, international organisations and governments for the elimination of child labour. The problem of child labour is complex and multifaceted and cannot be solved with a "one size fit all" policy.

The International Labour Organisation (ILO) estimated in 1998 that there are over 250 million children between the ages of five and fourteen who worked for part of the time. Of these, $61 \%$ are in Asia, 32\% in Africa and 7\% in Latin America. The problem is most severe in Africa where every two out of five children are engaged in child labour [1]. Asia experienced an increase in child labour due to poor economic growth.

\section{Child Labour in 5 Major South Asian Countries}

Although statistics on the number of economically active children differ but a conservative estimate is that some 20 - 30 million live in the five large South Asian countries. Children's workforce participation rates- the ratio of the number of child workers to the child population- range from just 1 percent in Sri Lanka to more than 27 percent in Nepal. The rates vary within countries and tend to be higher among boys and in rural areas. The higher workforce participation rates among boys is due to the fact that girls work in informal sectors, such as within the home or as housemaids, which are harder to capture by statistics. [2]

Children's workforce participation rates differ considerably in the region. Nepal with the highest rate has 26.5 percent of the child population working whereas the children's workforce participation rate for Sri Lanka is approximately 1.2 percent. Pakistan's overall rate of 15 percent is less than that of Nepal and Bangladesh but it has the second highest rate for the participation of boys in the workforce.

A comparison of the literacy ratios and the children's workforce participation rates reveals a negative correlation between the two. Sri Lanka with the highest literacy ratio in the region has the lowest incidence of children's participation in the workforce. On the other hand Nepal with the lowest literacy ratio has the highest rate of children's participation in the workforce. Pakistan has a literacy ratio, which is higher than Nepal and Bangladesh but lower than India and Sri Lanka, and the children's workforce.

Poverty and lack of resources are no doubt contributing factors to low literacy levels and a high incidence of child labour in a country. However, Sri Lanka is a prime example of a country setting its priorities in order and allocating its resources to achieve the objectives it had established.

\section{The Economic Framework for Analysing Child Labour}

Economics deals with the allocation of resources and the attainment of ends with limited resources.

"Economics is a science which studies human behaviour as a relationship between ends and scarce means which have alternative use" [3].

The underlying assumption of economic theory is that economic agents are rational and maximise their utility. Scarcity of resources implies that ends have to be prioritised to maximise satisfaction. How are resources allocated among alternative ends? Allocation of resources takes place at the macro level and at the micro level. The nation state is responsible for the allocation of resources at the macro level. At the household level it would involve the pursuit of self-defined goals. Who sets these goals within the household and who determines the intra household distribution of resources? Do all household members have equal claims on these resources? These 
are relevant questions when analysing child labour. The analysis involves understanding why a household will send a child to work rather than to school.

Both at the national and household levels the allocation of limited resources is critical for the attainment of predefined ends. At the national level the percentage of GDP devoted to the provision of primary education, social welfare and poverty alleviation programmes and the existence of a well functioning social safety net will determine the literacy levels and the incidence of child labour. At the household level the desire to educate children will be influenced by income levels, the quality of education, the cost of education and the contribution of education to enhanced earning capabilities both actual and perceived.

The decisions to allocate the scarce resources of a hous ehold are usually taken by the male head of the family. Is the decision to send a child to work a rational response to the economic incentives faced by the decision maker? Given the resources at the disposal of the household this may be the only way for the attainment of ends that in many cases involves mere survival.

"As long as individual agents behave rationally in response to market signals, the market will ensure that a multitude of potentially conflicting choices persistently converge towards a ' $P$ areto equilibrium: a condition where no one can become better off without someone else becoming worse off." [4]

A Pareto efficient allocation of resources is contradicted in reality by the existence of market failures. Some form of government intervention may be necessary to correct market failure.

The presence of child labour epitomises two externalities in the market. If a child is working then he or she is out of school thus the benefit of education, both private and spill over, is not captured by the market. In the labour market negative externalities are present. If the wages of parents is high enough there may not be any need for sending children to work. Basu identifies "multiple equilibria one in which wages are low and children work and another in which wages are high and children do not work." [5]

Child labour signifies a major source of market failure and one that justifies the intervention of the government. Government intervention can take different forms. Negative externalities can be reduced through the imposition of taxes or government regulations and positive externalities can be dealt with by either giving subsidies to the producers or consumers or by the government getting involved in direct production. The two dimensions of child labour in the form of negative externalities in the labour market and positive externalities for education need to be corrected.
The government can intervene in the labour market and ensure that legislation on child workers is implemented. There are many children who are not involved in the worst forms of child labour and may still be active in the labour market or they may be "no where" children (neither working nor going to school). In the case of girls, statistics fail to reflect the true gravity of the situation because either they are working in the informal sector or doing household chores at a very young age.

\section{Child Labour And Literacy In Pakistan: Sindh \& Other Provinces}

If a nation is able to provide free compulsory education to all is children there is less likelihood of the children entering the labour market. Sri Lanka is an example of a country that has achieved high literacy rates and low levels of children's participation in the labour market.

Using the statistics published in the labour force surveys the participation of 10-14 year old children in the labour force is analysed with respect to changes over time and between provinces. The incidence of poverty declined from 1986-87 to 1990-91 falling from 29 percent to 26 percent. However, since then the trend in poverty has reversed, the rural areas being the most adversely affected. In general the 1980s was a high growth era that saw declining poverty whereas during the 1990s the economy has been sluggish with rising poverty levels.

The figure below is based on the 1981 and 1998 census. The diversity in literacy levels is evident both in terms of variations among provinces and genders. The literacy level among women is very low 35.1 percent in Punjab, 34.8 percent in Sindh and a meagre 18.8 and 14.1 percent in NWFP and Baluchistan respectively. In 1981 both the male and female literacy ratios were the highest in Sindh compared to the other provinces. However, by 1998 Punjab had the highest literacy ratios for both the male and female populations and Baluchistan had the lowest literacy ratios in both categories.

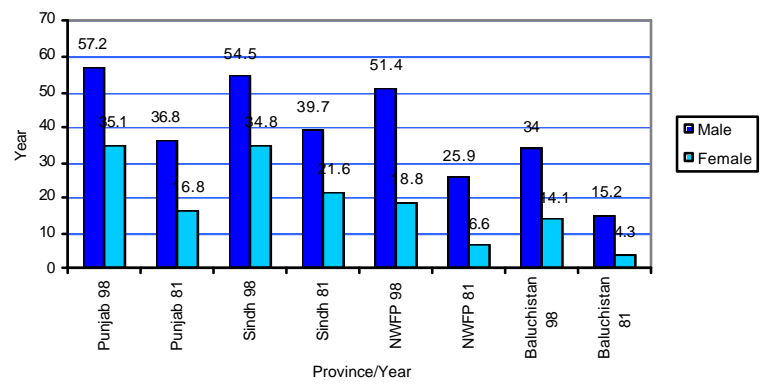

Figure 1. Pakistan Literacy Ratios Source: Economic Survey 2002-03, Government of Pakistan, Islamabad.

A comparison of literacy ratios between the urban and rural populations of Pakistan indicates that literacy levels are higher amongst the urban population compared to the 
rural population. The female population in rural areas has the least access to education as reflected in the lowst literacy rates. In Baluchistan more than 90 percent of the rural female population was illiterate in 1998. Sindh's literacy ratios both for the rural male and female population are better than Baluchistan but lower than Punjab and NWFP. The low liter acy levels among women can be explained by socio-cultural and religious factors.

A comparison of the poverty trend and participation in the labour force of children in the $10-14$ years age bracket (figure 2) indicates that an increase in poverty has a positive effect on the employment of boys but a negative effect on the employment of girls. This could be purely due to measurement problems since girls do not enter the formal sector and in many cases they are neither in the work force nor at school.

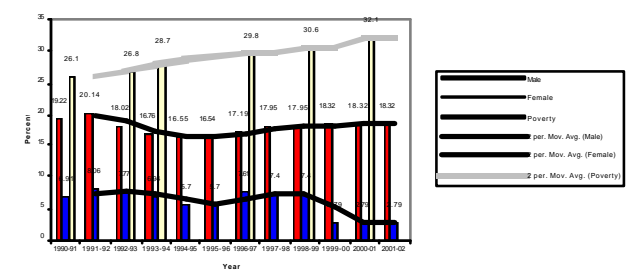

Figure 2. Labour Force Participation of 10 to 14 year old children. Source: Economic Survey 2002-03, Government of Pakistan, Islamabad.

It is imperative that we recognise the link between poverty and child labour. Poverty is a major factor in determining low literacy rates and a high incidence of child labour. It is not out of selfishness that a parent sends a child to work but in many circumstances it is an economic necessity for the survival of the family.

A comparison of the 1997-98 and 1999-2000 participation rates for economically active children in the age group of 10 to 14 years reveals that there are considerable variations among rural and urban populations. The incidence of child workers is highest in the rural areas across all provinces and this situation has not changed between 1997-98 and 1999-2000. Rural boys are the single most economically active group in all the provinces. The statistics do not reflect the economic participation of girls since their work in the house or the informal sector goes unrecorded. In 1997-98 the highest number of male workers in the 10-14-age group was in rural Sindh and the lowest number were in Baluchistan. However, the situation in Sindh had improved to some extent by 19992000 where the percent for males had declined. In the rural areas the participation rates of boys declined for both Sindh and Punjab but Baluchistan and NWFP experienced an increase. The statistics for girls is less reliable since it does not reflect the correct picture.
Policies to combat child labour in the rural areas need to be carefully designed to ensure that they are welfare enhancing rather than welfare diminishing.

\subsection{A Study of Daood Colony, Karachi}

The nature of this research was primarily qualitative and was conducted through interviews with the community leaders and the family members of 11 households. Within the locality the sample was random.

The average number of children in these households was 7.8. The high fertility rate $\mathrm{s}$ in itself a major contributing factor to the low standards of living and the inability of the households to send their children to school.

There were 86 children of which only 14 went to school. 10 children were in the $0-4$ age bracket and can be considered not to be of school going age. This meant that only 18 percent of the children went to school. The school enrolment rate was somewhat higher for boys than for girls ( $24 \%$ and $14 \%$ respectively).

Another interesting fact was that only 4 out these 86 children worked. Therefore majority of the children neither went to school nor to work. They were "nowhere" children.

Majority of these households were living below the poverty line. Consequently the most frequently stated reason for not sending the children to school was the inability of the family to pay for school uniforms and other incidental expenses. Although there was a free government school in the colony but still children were not sent.

In some cases the parents were keen to send their children to school but the children did not want to attend school.

The main conclusions that can be drawn from this field survey are that dealing with the problem of child labour is linked to the income levels of families and the ability of the state to provide free, good quality schooling. It is imperative that social safety nets are in place to support families who fall below the poverty line.

\section{A Model for Children Education in Pakistan.}

In Pakistan the public sector has failed to provide widespread quality education. This is evident in the general decline of educational standards and the perception of households. A low-income household would rather pay fees and send children to a private school rather than take advantage of free government schooling. If a child is in school he or she will not be economically active. A schooling system that provides access to education to all children both male and female will also ensure that "no where" children are kept out of the labour market. The two most common reasons for children not being sent to school are poverty and lack of confidence in the public sector schooling system. Both these problems 
can be overcome to some extent by introducing a voucher system that households can redeem for education.

The vouchers can be given per child of school going age and should be redeemable at any private school. The advantage of this scheme will be that the households' income will be augmented but spending will be restricted to education.

There is no doubt that there is inefficiency in the utilization of resources in the public sector. In addition lack of accountability leads to very poor quality teaching. Competition among private schools will ensure a better quality of education. The recipients of education vouchers will have an incentive to redeem them for primary education for their children. They will have more confidence in the quality of education since they will have a choice of schools rather than being forced to go to the local government school.

\section{Conclusion and Recommendations.}

Why are children sent to work and not to school? The initial response is due to poverty. The families that make this choice are doing so out of necessity. There is an opportunity cost of sending children to school consisting of income forgone and the expenses associated with sending children to school. Some families are unable to take advantage of free government schooling because they cannot afford the books and school uniforms. A desegregated approach to policy formulation that involves an input from community leaders, educationalists, the households and the government will be more effective and sustainable.

\section{Acknowledgement}

I am grateful to Dr. Jalbani for his kind support and valuable feedback.

\section{REFERENCES}

[1] Mehta, P. S. "Child Labour: Can Trade Sanctions or Boycotts lead to Elimination?", The Courier ACP-EU September-October 2001

[2] "Addressing Child Labour in South Asia", The World Bank Group, January 2000

[3] Robbins, L. An Es say on the Nature and Significance of Economic Science. Macmillan, 1935

[4] Kabeer. N. "The Theoretical Underpinnings of WID" Reversed Realities. OUP, 1994

[5] Basu, K. and Van, P.H. "The Economics of Child Labor", The American Economic Review, June 1998. 